Article

\title{
Interface Compositions as Determinants of Resveratrol Stability in Nanoemulsion Delivery Systems
}

\author{
Adela Mora-Gutierrez ${ }^{1, *}$, Rahmat Attaie ${ }^{1}$, Maryuri T. Núñez de González ${ }^{1}$, Yoonsung Jung ${ }^{1}$ and \\ Sixto A. Marquez ${ }^{2}$ \\ 1 Cooperative Agricultural Research Center, Prairie View A\&M University, Prairie View, TX 77446, USA; \\ rattaie@pvamu.edu (R.A.); mtnunez@pvamu.edu (M.T.N.d.G.); yojung@pvamu.edu (Y.J.) \\ 2 Department of Horticultural Sciences, Texas A\&M University, College Station, TX 77843, USA; \\ sixto46@tamu.edu \\ * Correspondence: admora@pvamu.edu; Fax: +1-936-261-9975
}

Received: 9 September 2020; Accepted: 30 September 2020; Published: 2 October 2020

\begin{abstract}
The incorporation of hydrophobic ingredients, such as resveratrol (a fat-soluble phytochemical), in nanoemulsions can increase the water solubility and stability of these hydrophobic ingredients. The nanodelivery of resveratrol can result in a marked improvement in the bioavailability of this health-promoting ingredient. The current study hypothesized that resveratrol can bind to caprine casein, which may result in the preservation of the biological properties of resveratrol. The fluorescence spectra provided proof of this complex formation by demonstrating that resveratrol binds to caprine casein in the vicinity of tryptophan amino acid residues. The caprine casein/resveratrol complex is stabilized by hydrophobic interactions and hydrogen bonds. Hence, to study the rate of resveratrol degradation during processing/storage, resveratrol losses were determined by reversed-phase high performance liquid chromatography (RP-HPLC) in nanoemulsions stabilized by bovine and caprine caseins individually and in combination with polysorbate-20. At $48 \mathrm{~h}$ oxidation, $88.33 \%$ and $89.08 \%$ was left of resveratrol in the nanoemulsions stabilized by caprine casein $\left(\alpha_{\mathrm{s} 1}-\mathrm{I}\right) /$ polysorbate-20 complex and caprine $\left(\alpha_{\mathrm{s} 1}-\mathrm{II}\right) /$ polysorbate-20 complex, while there was less resveratrol left in the nanoemulsions stabilized by bovine casein/polysorbate-20 complex, suggesting that oxygen degradation was involved. The findings of this study are crucial for the food industry since they imply the potential use of caprine casein/polysorbate-20 complex to preserve the biological properties of resveratrol.
\end{abstract}

Keywords: resveratrol; casein; bovine; caprine; polysorbate-20; nanoemulsion delivery systems

\section{Introduction}

Resveratrol (trans-3, 4', 5-trihydroxy stilbene), which is mainly found in grapes and red wine, is a phytochemical with several potent biological activities such as antioxidant, anti-inflammatory, cardio-protective, neuroprotective, chemo-preventive, and anti-aging [1-4]. Since resveratrol utilization in aqueous foods is limited by its poor bioavailability due, in large part, to its poor aqueous solubility, and to its tendency to be unstable due to auto-oxidation and photosensitivity $[5,6]$, there is a need for developing nanoemulsion delivery systems to enhance the water solubility and stability of resveratrol [7].

Emulsion droplets are a hydrophobic domain readily dispersed in aqueous foods. The lipid phase serves as a reservoir for other hydrophobic ingredients (e.g., flavors, nutrients, phytochemicals) which provides some protection against losses by chemical reactions and can limit or control their release [8]. The stability of emulsions in complex liquid systems is critical in order to provide a homogeneous 
product with the desired visual appearance, mouthfeel, texture, and shelf-life stability [9]. Caseins ( $\alpha_{\mathrm{s} 1^{-}}$, $\left.\alpha_{\mathrm{s} 2^{-},},-, \mathrm{k}-\right)$ are widely valued for their emulsifying properties. The stability behavior of oil-in-water emulsions based on caseins is related to their structure and mechanical properties of adsorbed layers at the surface of the droplets [10]. When surfactants are used together with casein, competitive adsorption of two components toward the interface occurs [11], thereby leading to some emulsion instability by reduced steric and electrostatic repulsion [12]. However, very low concentrations of surfactants improve the role of casein at the oil-in-water interface at acidic $\mathrm{pH}$ [13], and the $\mathrm{pH}$ of milk (6.67) [14]. The roles of $\alpha_{\mathrm{s} 1^{-}}, \alpha_{\mathrm{s} 2^{-}}, \beta-$, and $\mathrm{k}$-casein in the interaction of polysorbate-20 with bovine and caprine caseins at the oil-water interface in resveratrol-enriched nanoemulsions have prompted this investigation. Therefore, the purpose of this study was to prepare resveratrol-loaded nanoemulsions with bovine and caprine caseins individually and in combination with polysorbate- 20 to evaluate their effects on the degradation of resveratrol during processing/storage. Spectroscopic methods were used to elucidate the interaction of polysorbate- 20 with bovine and caprine caseins in solution prior to their use as emulsifiers (stabilizers) in resveratrol-loaded nanoemulsions.

\section{Materials and Methods}

\subsection{Materials}

Resveratrol (purity $>99.0 \%$ ), polysorbate-20, $\beta$-casein from bovine milk (purity $>90 \%$ ), ethanol (200 proof, purity $>99.5 \%$ ), dimethyl sulfoxide (DMSO), and thimerosal were purchased from Sigma-Aldrich (St. Louis, MO, USA) and Thermo Fisher Scientific (Waltham, MA, USA). Medium-chain triglycerides (Neobee ${ }^{\circledR}$ M- 5) was kindly donated by Stepan Company (Northfield, IL, USA). The analytical grade extraction solvents and HPLC-grade solvents were purchased from Thermo Fisher Scientific. Deionized water, prepared by passing distilled water over a mixed bed of cation-anion exchangers, was used throughout this study.

\subsection{Preparation of Bovine and Caprine Caseins}

The caprine caseins characterized by a high content of $\alpha_{\mathrm{s} 1}$-casein (type I) and $\alpha_{\mathrm{s} 1}$-casein (type II) were obtained from a French Alpine goat and an Anglo-Nubian goat, respectively [15]. Bovine casein was obtained from the milk of a Jersey cow. Briefly, casein was prepared from skimmed milk by precipitating at $\mathrm{pH} 4.6$ and $30^{\circ} \mathrm{C}$, neutralizing at $\mathrm{pH} 7.0$, dialyzing against deionized water, and lyophilizing. The integrity of the samples was confirmed by sodium dodecyl sulfate-polyacrylamide gel electrophoresis (SDS-PAGE) and densitometry was used to assess the relative concentration of casein components [16].

\subsection{Preparation of Caprine $\beta$-Casein}

Caprine $\beta$-casein was prepared by urea fractionation [17] followed by column chromatography on DEAE-cellulose in urea [17]. Most of the caprine $\beta$-casein was eluted in two sequential peaks designated fraction I (tubes 29 thru 31) and fraction II (tubes 42 thru 46). These two fractions were found by SDS-PAGE and densitometry to contain 98 and 95\% of caprine $\beta$-casein, respectively [16]. These electrophoretic peaks possibly correspond to the caprine $\beta$-casein variants $A$ and $C$ of Moatsou et al. [18].

\subsection{Fluorescence Spectroscopy}

The fluorescence studies were performed on a Shimadzu spectrofluorometer RF-5000 (Shimadzu Corporation, Columbia, MD, USA) at $25^{\circ} \mathrm{C}$, using microcells with a working volume of $250 \mu \mathrm{L}$ and a path length of $5 \mathrm{~mm}$. The bovine and caprine caseins (in $5 \mathrm{mM}$ phosphate buffer, $\mathrm{pH}$ 7.0) were excited at $280 \mathrm{~nm}$ and their emission spectra were recorded individually and in combination with polysorbate- 20 at $25{ }^{\circ} \mathrm{C}$. Polysorbate- 20 was added to the protein solution in the cuvette, mixed and 
spectra were recorded after standing for $2 \mathrm{~min}$. The concentration of bovine casein or caprine casein was $0.1 \mathrm{mg} / \mathrm{mL}$ and polysorbate- 20 was $1 \mu \mathrm{M}$.

To study the interaction of resveratrol with bovine and caprine caseins, a stock solution $(1000 \mu \mathrm{M})$ of resveratrol was prepared by dissolving resveratrol in $1.25 \%(v / v)$ ethanol in water. This concentration of ethanol is not detrimental to protein structure [19]. The resveratrol $(1000 \mu \mathrm{M})$ was dissolved by continuous stirring. Samples for fluorescence measurement were prepared by mixing required volumes of the stock solution of resveratrol $(1000 \mu \mathrm{M})$ and casein (bovine vs. caprine) and water to make a final volume of $10 \mathrm{~mL}$. Resveratrol (in $5 \mathrm{mM}$ phosphate buffer, $\mathrm{pH}$ 7.0) was excited at its $\lambda_{\max }$ (adsorption) of 308 and the emission spectra were recorded between 360 and $580 \mathrm{~nm}$ at $25^{\circ} \mathrm{C}$. Emission spectra were recorded in the concentration range mentioned in the legends of figures.

\subsection{Circular Dichroism (CD) Spectroscopy}

Circular dichroism (CD) experiments were carried out with bovine $\beta$-casein and caprine $\beta$-casein $(0.1 \mathrm{mg} / \mathrm{mL})$ in $5 \mathrm{mM}$ potassium phosphate buffer at $\mathrm{pH}$ 7.0. Polysorbate-20 was added to the bovine and caprine $\beta$-casein samples at concentrations of $1 \mu \mathrm{M}, 10 \mu \mathrm{M}$, and $100 \mu \mathrm{M}$. Samples were filtered through $0.45-\mu \mathrm{m}$-pore filters into a jacketed $0.5-\mathrm{mm}$-pathlength cylindrical cell made of far-UV quartz. CD spectra were recorded on an AVIV 60DS spectropolarimeter (Aviv Associates, Lakewood, NJ, USA) calibrated with $d$-10-camphorsulfonic acid. Successive measurements in the far-UV (190-250 nm) were made at $25{ }^{\circ} \mathrm{C}$. Background contributions from the buffer or polysorbate-20 were subtracted. Ellipticities $(\theta)$ are reported as deg $\mathrm{cm}^{2} \mathrm{dmol}^{-1}$. Secondary structure was estimated using CAPITO (http://capito.nmr.leibniz-fli.de) [20].

\subsection{Resveratrol Binding to Bovine and Caprine Caseins in Solution}

To evaluate the ability of the bovine and caprine caseins to bind resveratrol, mixtures of the casein solutions $(2 \% w / w)$ dissolved in $5 \mathrm{mM}$ phosphate buffer $(\mathrm{pH} 7.0)$ solution and resveratrol dissolved in ethanol $(1.25 \% v / v)$, at a concentration of $500 \mu \mathrm{g} / \mathrm{mL}$ in the final mixture, were mixed using a magnetic stirrer at low speed for $30 \mathrm{~min}$ at $25^{\circ} \mathrm{C}$. The samples were then vortexed and incubated for 5 days at $25^{\circ} \mathrm{C}$. After 5 days of incubation at $25^{\circ} \mathrm{C}$, samples were centrifuged at $10,000 \times g$ (Beckman Instruments) for $15 \mathrm{~min}$ and the supernatant $(0.05 \mathrm{~mL})$ was diluted in $3.95 \mathrm{~mL}$ of DMSO. The unbound resveratrol was quantified by measuring the solution absorbance at 309 using a UV/vis model DU-530 spectrophotometer (Beckman Instruments) [21]. A solution of bovine casein or caprine casein in DMSO without resveratrol was used as a blank. Resveratrol dissolved in DMSO was used to construct a calibration curve with concentrations ranging from $1 \mu \mathrm{g} / \mathrm{mL}$ to $1000 \mu \mathrm{g} / \mathrm{mL}$. More than $98.5 \%$ of resveratrol was bound to the bovine and caprine caseins.

\subsection{Preparation of Resveratrol-Loaded Nanoemulsions}

The oil phase consisted of medium-chain triglycerides (MCT). The aqueous phase consisted of $2 \%(w / w)$ of bovine casein or caprine casein bound to resveratrol dissolved in a buffer solution $(5 \mathrm{mM}$ phosphate buffer, $\mathrm{pH} 7.0)$ containing an anti-microbial $(1 \mathrm{mM} w / v)$ thimerosal. The final resveratrol concentration of the initial nanoemulsions stabilized by bovine and caprine caseins was as follows: $493 \mu \mathrm{g} / \mathrm{mL}$ (bovine), $496 \mu \mathrm{g} / \mathrm{mL}$ (caprine $\alpha_{\mathrm{s} 1}-\mathrm{I}$ ) and $497 \mu \mathrm{g} / \mathrm{mL}$ (caprine $\alpha_{\mathrm{s} 1}-\mathrm{II}$ ).

Coarse emulsions were formed by homogenizing $5 \%(w / w)$ of the oil phase with $95 \%(w / w)$ of the aqueous phase for 5 min with a handheld homogenizer (Biospec Products, Inc., Bartlesville, OK, USA) at low speed. In emulsions with polysorbte-20, $1000 \mu \mathrm{M}$ of polysorbate-20 was added to the water phase before emulsification. The coarse emulsion was then homogenized five times at $100 \mathrm{MPa}$ through a high-pressure TC5 homogenizer (Stansted Fluid Power, Harlow, UK). The emulsions were transferred to $50-\mathrm{mL}$ Pyrex amber bottles and kept at $25^{\circ} \mathrm{C}$ for $48 \mathrm{~h}$ in darkness. The quantity of resveratrol in nanoemulsions was monitored by RP-HPLC at $6,12,24$, and $48 \mathrm{~h}$.

The concentrations of unabsorbed proteins (emulsifiers) in the aqueous phase at $6 \mathrm{~h}$ and $48 \mathrm{~h}$ of incubation were measured as follows: aliquots of emulsions were centrifuged at $13,000 \times g$ (Beckman 
Instruments) for $30 \mathrm{~min}$ to separate the aqueous phase from the oil droplets. The aqueous phase was collected and filtered through a $0.10 \mu \mathrm{m}$-cellulose acetate filter (Sterlitech Corporation, Kent, WA, USA) to remove the small oil droplets. The amount of unabsorbed proteins in the aqueous phase of the emulsions was determined according to the method of Markwell et al. [22].

\subsection{Physical Characterization of Resveratrol-Loaded Nanoemulsions}

The particle size of the oil droplets in the resveratrol-loaded emulsions was measured at $0 \mathrm{~h}$ and $48 \mathrm{~h}$ of storage (at $25^{\circ} \mathrm{C}$ ) after homogenization with a SALD-2101 laser diffraction particle analyzer (Shimadzu Corporation, Columbia, MD, USA). The charge of the oil droplets in the resveratrol-loaded emulsion (zeta potential, $\zeta, \mathrm{mV}$ ) was measured at $0 \mathrm{~h}$ and $48 \mathrm{~h}$ of storage (at $25^{\circ} \mathrm{C}$ ) with a Zetasizer Nano ZS (Malvern Instruments, Worcestershire, UK). Samples were diluted 100 times in $5 \mathrm{mM}$ phosphate buffer at $\mathrm{pH}$ 7.0.

\subsection{Quantification of Resveratrol in Nanoemulsions}

The resveratrol contents of the nanoemulsions were determined using RP-HPLC. Five milliliters of nanoemulsion were deproteinized by mixing with $1 \mathrm{~mL}$ of $1 \mathrm{M} \mathrm{HCl}$ and then $10 \mathrm{~mL}$ of acetonitrile was added to the mixture followed by vortex-mixing for $1 \mathrm{~min}$. The supernatant was filtered (Whatman \#541, Whatman International Ltd., Maidstone, UK) and collecting approximately $7 \mathrm{~mL}$ of filtrate. An aliquot $(1 \mathrm{~mL})$ of filtrate was collected and passed through a $0.45 \mu \mathrm{m}$ syringe filter into a $2 \mathrm{~mL}$ amber vial. The sample solution $(10 \mu \mathrm{L})$ was injected into an HPLC system.

The HPLC (Waters Corporation, Milford, MA, USA) instrument was equipped with a 515 pump, Waters auto-sampler model 717, a Waters C18 column (reversed phase, $250 \mathrm{~mm} \times 4.6 \mathrm{~mm}$, I. D., $5 \mu \mathrm{m}$ ), and a UV-visible photodiode array detector model 2489. Empower 2 software was used for analysis. The mobile phase consisted of a mixture of methanol: $10 \mathrm{mM}$ potassium dihydrogen phosphate buffer ( $\mathrm{pH}$ 6.8): acetonitrile $(63: 30: 7, v / v / v)$ at a constant flow rate of $1 \mathrm{~mL} / \mathrm{min}$ at $25^{\circ} \mathrm{C}$. Chromatographic analysis was conducted in isocratic mode, and the detection was carried out at $306 \mathrm{~nm}$. An injection volume of $10 \mu \mathrm{L}$ was used for all standards.

The calibration curve was constructed using resveratrol $(10 \mu \mathrm{g}$ to $500 \mu \mathrm{g} / \mathrm{mL})$ with a correlation coefficient of 0.999 . The elution time of trans-resveratrol was $2.817 \mathrm{~min}$. All samples and standards were protected from light to avoid photochemical isomerization of resveratrol from trans to cis form.

\subsection{Statistical Analysis}

All experiments were conducted in triplicate and the data were analyzed using SAS 9.4 program (SAS Institute Inc., Cary, NC, USA). All data analyses were conducted by the PROC MIXED procedure of SAS. Tukey's test applied for multiple comparisons at a significance level of $\alpha=0.05 \%$. Comparisons between the treatments with the responses for particle size and zeta potential were based on complete randomized design and used one-way analysis of variance (ANOVA). The treatment comparison for resveratrol (\%) was conducted on two factorial design for emulsifier and time and used two-way analysis of variance (ANOVA).

\section{Results and Discussion}

\subsection{Characterization of Bovine and Caprine Caseins}

Caprine milk contains the same four casein fractions that bovine milk has, i.e., $\alpha_{\mathrm{s} 1^{-}}, \alpha_{\mathrm{s} 2^{-}}, \beta-$, and $k$-caseins [23], but the $\alpha_{\mathrm{s} 1}$-casein fraction has very large individual quantitative variations among animals, partly due to the occurrence of genetic polymorphism [24]. This polymorphism gives rise to great variations in $\alpha_{\mathrm{s} 1}$-casein content of caprine milks from about $25 \%$ in certain caprine milks to total lack of it in others. In bovine milk, the consistency of the ratio of caseins in forming the structure of micelles aids in good quality products, whereas the variability of the casein ratio $\left(\alpha_{\mathrm{s} 1}-\right.$ to $\left.\alpha_{\mathrm{s} 2}-\right)$ in 
particular affects the micelle structure, which may lead to caprine milk products of differing quality, especially cheeses.

The electrophoretic $\alpha_{\mathrm{s} 1}$-band of slower mobility (labeled as $\alpha_{\mathrm{s} 1}$-I) in Table 1 seems to correspond to the $\alpha_{\mathrm{s} 1}$-E protein. The electrophoretic band labeled as $\alpha_{\mathrm{s} 1}$-II in Table 1 possibly corresponds to the sum of contributions from $\alpha_{\mathrm{s} 1}-\mathrm{A}, \mathrm{B}$ or $\mathrm{C}$ variants [25]. The SDS-PAGE findings regarding the genetic polymorphism in the caprine casein $\left(\alpha_{\mathrm{s} 1}-\mathrm{I}\right)$ and caprine casein $\left(\alpha_{\mathrm{s} 1}-\mathrm{II}\right)$ samples used in this study should be interpreted with caution. Hence, the bands labeled as $\alpha_{\mathrm{s} 1}-\mathrm{I}$ and $\alpha_{\mathrm{s} 1}-\mathrm{II}$ are regarded as a trunked version of $\alpha_{\mathrm{s} 1}$-casein (Table 1). Moreover, the $\beta$-casein content of caprine casein $\left(\alpha_{\mathrm{s} 1}-\mathrm{I}\right)$ and caprine casein $\left(\alpha_{\mathrm{s} 1}-\mathrm{II}\right)$ is markedly higher than that of bovine casein (Table 1$)$. The high hydrophobic character of the $\beta$-casein fraction [26] makes the caprine casein $\alpha_{\mathrm{s} 1}$-I and caprine casein $\alpha_{\mathrm{s} 1}$-II suitable candidates as encapsulating agents for hydrophobic ingredients such as omega-3 fatty acids, carotenoids [27,28], and resveratrol (this study) in food emulsions.

Table 1. Casein distribution of caprine caseins compared with a typical bovine casein ${ }^{1}$.

\begin{tabular}{cccccc}
\hline \multicolumn{7}{c}{ Casein Fraction \% } \\
Sample & $\boldsymbol{\alpha}_{\mathbf{s} 2}$ & $\boldsymbol{\alpha}_{\mathbf{s} 1}$ & $\boldsymbol{\alpha}_{\mathbf{s} 1}$ & $\boldsymbol{\beta}$ & $\boldsymbol{\kappa}$ \\
\hline Caprine casein high in $\alpha_{\mathrm{s} 1}$-casein-I & 9.2 & 4.0 & 21.1 & 51.6 & 13.8 \\
Caprine casein high in $\alpha_{\mathrm{s} 1 \text {-casein-II }}$ & 5.3 & & 25.6 & 60.6 & 9.6 \\
Bovine casein & 12.1 & & 39.5 & 37.2 & 11.2 \\
\hline
\end{tabular}

${ }^{1}$ From Mora-Gutierrez et al. [28].

\subsection{Binding of Polysorbate-20 to Caprine Casein in Solution}

The understanding of the fluorescence properties of tryptophan is vital for its use as an intrinsic probe of protein structure and dynamics $[29,30]$. The subtle changes in fluorescence that are associated with changes in protein environment are revealed by fluorescence spectroscopy. Tryptophan is one of the major chromophores among the naturally occurring amino acids and is responsible for the absorbance shown by proteins at $280 \mathrm{~nm}$. Bovine casein contains five tryptophan residues, of which Trp-164 and Trp-199 locate at $\alpha_{\mathrm{s} 1}$-casein, Trp-109 and Trp-193 at $\alpha_{\mathrm{s} 2}$-casein, and Trp-143 locates at $\beta$-casein [26]. These tryptophan residues contribute mainly to the intrinsic fluorescence of bovine casein. In the case of caprine casein, amino acid sequences located in homologous positions in homologous caseins may be different. In this study, the existence of such differences in caprine casein from bovine casein is suggested but not proven [28].

The environment of tryptophan residues appears to be perturbed by the binding of polysorbate-20 to caprine casein $\left(\alpha_{\mathrm{s} 1}-\mathrm{II}\right)$ (Figure 1). A subtle shift in the wavelength of maximum emission $\left(\lambda_{\max }\right)$, from 357 to 352 under solution conditions suggests that the tryptophan residues of caprine casein $\left(\alpha_{s 1}-\mathrm{II}\right)$ were in a relatively more hydrophobic environment upon binding to polysorbate-20 (Figure 1 ). The intrinsic fluorescence intensity of caprine casein $\left(\alpha_{\mathrm{s} 1}\right.$-II) decreased (Figure 1$)$. The quenching of caprine casein $\left(\alpha_{\mathrm{s} 1}-\mathrm{II}\right)$ by polysorbate- 20 is induced by complex formation (Figure 1 ). Polysorbate-20 seems to associate with caprine casein $\left(\alpha_{\mathrm{s} 1}-\mathrm{II}\right)$ and modify the surface of caprine casein $\left(\alpha_{\mathrm{s} 1}-\mathrm{II}\right)$, and the hydrophobic interior of caprine casein $\left(\alpha_{\mathrm{s} 1}-\mathrm{II}\right)$ could be made more accessible for polysorbate-20 [31]. These results reflect the hydrophobic tryptophan environment in the solvent accessible region of caprine casein/polysorbate-20 complex. 


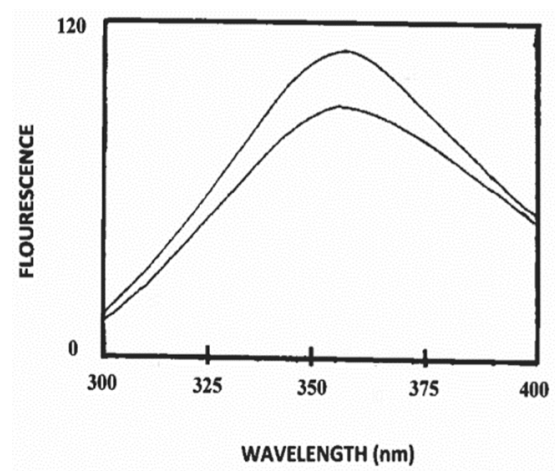

Figure 1. Fluorescence emission spectra (excitation wavelength $280 \mathrm{~nm}$ ) of bovine casein alone and in combination with polysorbate- 20 at $25^{\circ} \mathrm{C}$ in $5 \mathrm{mM}$ phosphate buffer, $\mathrm{pH}$ 7.0. Traces, from top to bottom, are bovine casein $(0.1 \mathrm{mg} / \mathrm{mL})$; and bovine casein $(0.1 \mathrm{mg} / \mathrm{mL})$ with added polysorbate-20 $(1 \mu \mathrm{M})$.

\subsection{Estimation of Secondary Structure of $\beta$-Casein/Polysorbate-20 Complex in Solution}

The high surface activity and bio-function of casein micelles from bovine milk are largely related to $\beta$-casein; thus, the study of the individual structural property of $\beta$-casein plays a key role in understanding the structure/function relationship of casein micelles from commercially important ruminant species [32]. The fractionation of $\beta$-casein from caprine casein is shown in Figure 2. To determine its potential for interacting with other components of the caprine casein micelles, the caprine $\beta$-casein fraction of Figure 2a was investigated by circular dichroism (CD) spectroscopy.
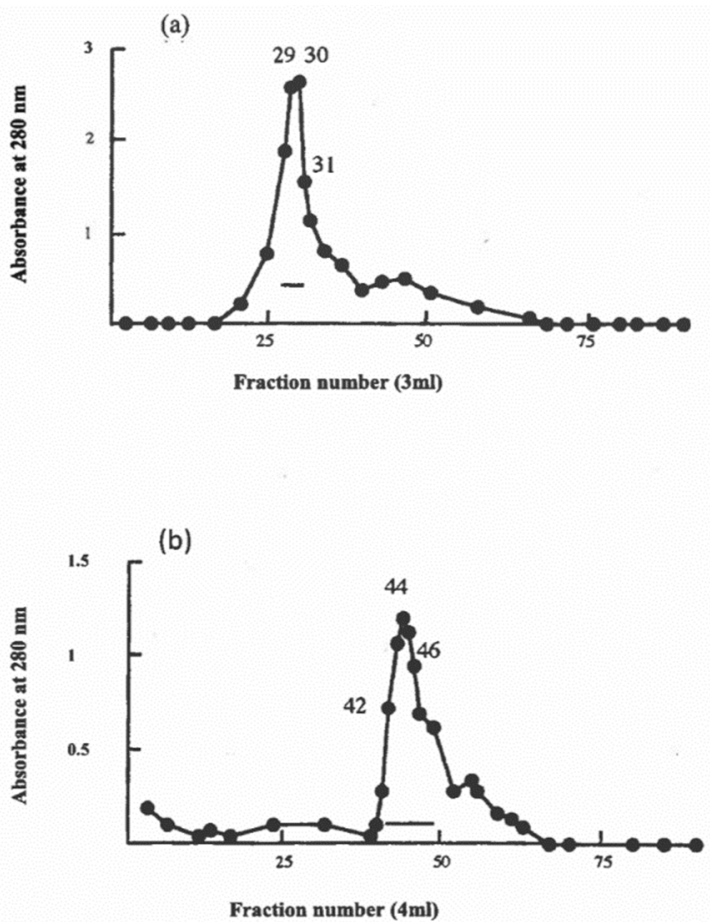

Figure 2. Fractionation of caprine $\beta$-casein by DEAE-cellulose chromatography. Fraction I (a) and Fraction II (b).

Figure 3 shows the mean residue ellipticity $(\theta)$ as a function of wavelength in the far-UV region for the caprine $\beta$-casein/polysorbate- 20 complex at $25^{\circ} \mathrm{C}$. The CAPITO analysis (Table 2 ) of the CD spectra shows a helical conformational stabilizing effect of polysorbate- 20 on caprine $\beta$-casein. Hydrogen binding derived from hydroxyl groups of polysorbate- 20 with amino acid residues of protein plays a key role in the formation of a hydrogen bond network for stabilizing the helical conformational change induced by surfactant, as previously observed in $\alpha$-lactalbumin [33]. 
Table 2. Secondary structure of bovine and caprine $\beta$-caseins in the presence or in the absence of polysorbate-20.

\begin{tabular}{ccccc}
\hline \multicolumn{4}{c}{$\beta$-Casein/Polysorbate-20 Samples } \\
\hline $\begin{array}{c}\text { Conformational } \\
\text { Element * }\end{array}$ & Bovine $\beta$-Casein & $\begin{array}{c}\text { Bovine } \\
\beta \text {-Casein/PS-20 1 }\end{array}$ & Caprine $\beta$-Casein & $\begin{array}{c}\text { Caprine } \\
\beta \text {-Casein/PS-20 }\end{array}$ \\
\hline$\alpha$-helix (\%) & 13.5 & 16.8 & 14.2 & 17.8 \\
$\beta$-strand (\%) & 17.9 & 21.0 & 16.8 & 22.5 \\
Irregular (\%) & 69.1 & 62.7 & 70.3 & 61.6 \\
\hline
\end{tabular}

${ }^{1}$ PS-20, polysorbate-20. * Analysis of secondary structure of $\beta$-casein/PS-20 samples was processed by the CAPITO program [20].

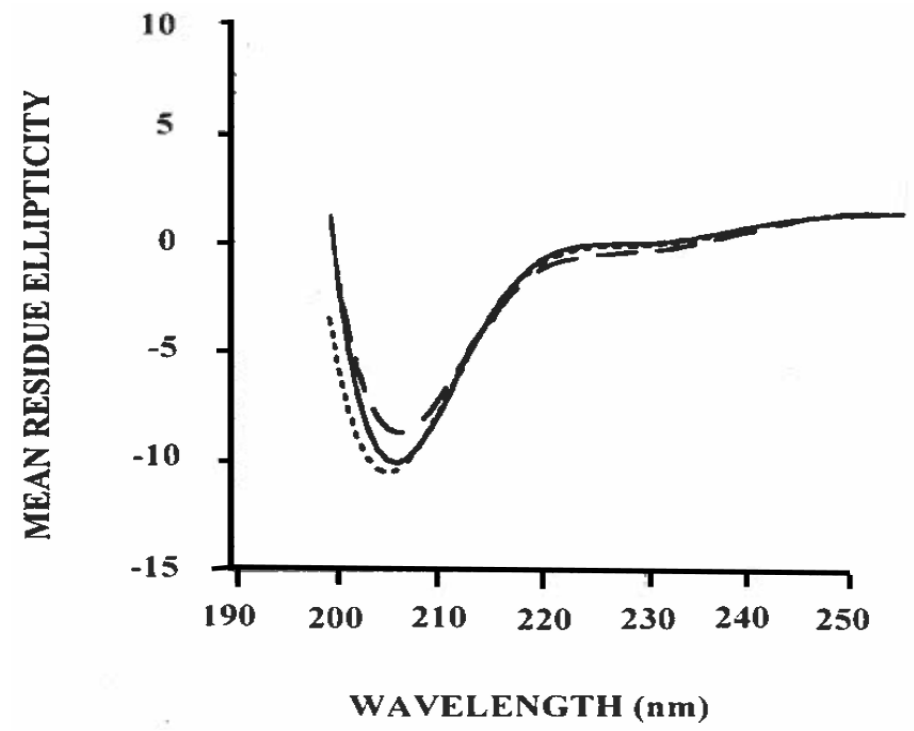

Figure 3. Circular dichroism spectra of caprine $\beta$-casein $(0.1 \mathrm{mg} / \mathrm{mL})$ in combination with polysorbate-20 at $25^{\circ} \mathrm{C}$ in $5 \mathrm{mM}$ phosphate buffer, $\mathrm{pH}$ 7.0. - - $1 \mu \mathrm{M}$ polysorbate-20; $10 \mu \mathrm{M}$ polysorbate-20;

- - - $100 \mu \mathrm{M}$ polysorbate-20.

In the case of bovine $\beta$-casein, the secondary structure content showed $13.5 \%$ of $\alpha$-helical, $17.9 \%$ of $\beta$-sheet, and $69.1 \%$ of irregular conformation (Table 2 ), indicating the intrinsically disordered structure of bovine $\beta$-casein [34]. Upon binding with polysorbate-20, the content of $\alpha$-helical, $\beta$-sheet and irregular conformation was calculated as $16.8 \%, 21.0 \%$, and $62.7 \%$, respectively, suggesting that the $\alpha$-helical and $\beta$-sheet conformation of bovine $\beta$-casein increased, but the irregular structure was reduced. The $C D$ data suggest that the changes in the secondary structure of bovine $\beta$-casein induced by polysorbate-20 are related to the disordered regions and the hydrophobic domains of this protein [34]. The lauric acid chains of polysorbate-20 may be aligned along the $\alpha$-helical and $\beta$-sheet structures in order to stabilize disordered regions and expose aromatic residues of bovine $\beta$-casein, thereby increasing the secondary structure of bovine $\beta$-casein [35]. The hydrophobic interactions and hydrogen bonds are the main factors governing the stabilization $[33,34,36]$.

The data of Figure 3 show the potential of an $\alpha$-helical-like structure for caprine casein $\left(\alpha_{\mathrm{s} 1}\right.$-II $)$ upon binding to polysorbate-20 (Table 2). Such structures could be important in the stabilization of hydrophobic $\beta$-casein aggregates. Previous work demonstrated that the stabilization of the hydrophobic region in $\alpha_{\mathrm{s} 1}$-casein-k-casein interactions results in the ability of k-casein to stabilize $\alpha_{\mathrm{s} 1}$-casein. Hydrophobic amino acids play an important role in casein-casein interactions and therefore determine, to some extent, a variety of milk product functional properties, such as foaming, gelation and emulsification. These results confirm that the complex milk protein system plays a central role in the formation of micellar casein in this system. 


\subsection{Binding of Resveratrol to Bovine and Caprine Caseins in Solution}

The effect of increasing molar ratios of caprine casein $\left(\alpha_{\mathrm{s} 1}\right.$-II $)$ on the fluorescence emission spectrum of resveratrol was studied and the results are shown in Figure 4. When excited at its adsorption maximum of $308 \mathrm{~nm}$, resveratrol exhibited a fluorescence emission with a peak at around $459 \mathrm{~nm}$. The addition of caprine casein ( $\alpha_{\mathrm{s} 1}$-II) at molar ratios of 1, 10, 20, and 30 resulted in a dose-dependent quenching of the fluorescence peak of resveratrol, thus confirming the binding of caprine casein $\left(\alpha_{\mathrm{s} 1}\right.$-II) to resveratrol. As reported with the bovine casein/resveratrol complex [37], the caprine casein $\left(\alpha_{\mathrm{s} 1}\right.$-II)/resveratrol complex is likely to be stabilized by hydrophobic interactions and hydrogen bonds.

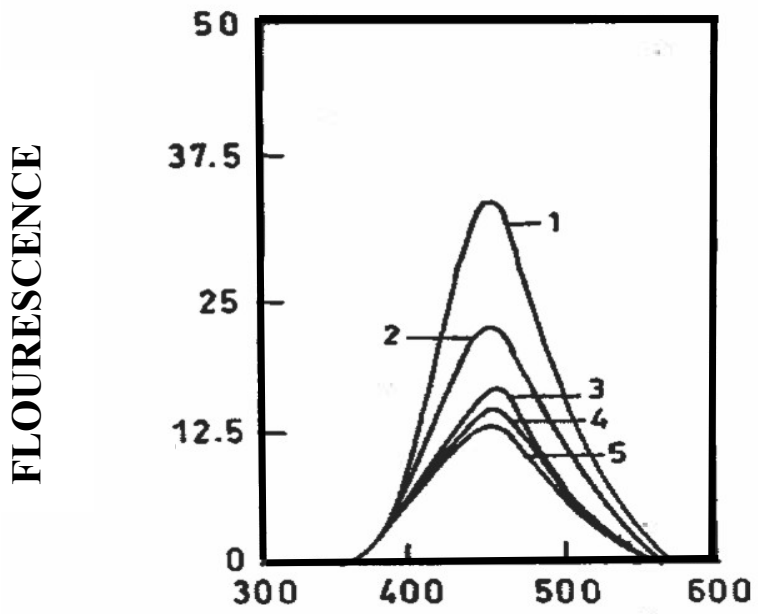

WAVELENGTH (nm)

Figure 4. Fluorescence emission spectra of resveratrol at $25^{\circ} \mathrm{C}$. Resveratrol (in $5 \mathrm{mM}$ phosphate buffer, $\mathrm{pH}$ 7.0), was excited at its $\lambda_{\max }$ (adsorption) of 308 and the emission spectra were recorded between 360 and $580 \mathrm{~nm}$. Trace 1: resveratrol alone $(5 \mu \mathrm{M})$; Trace 2: resveratrol: caprine casein $\left(\alpha_{\mathrm{s} 1}\right.$-II) molar ratio 1:1; Trace 3: resveratrol: caprine casein $\left(\alpha_{\mathrm{s} 1}-\mathrm{II}\right)$ molar ratio 1:10; Trace 4: resveratrol: caprine casein $\left(\alpha_{\mathrm{s} 1}\right.$-II $)$ molar ratio 1:20; Trace 5: resveratrol: caprine casein $\left(\alpha_{\mathrm{s} 1}-\mathrm{II}\right)$ molar ratio 1:30.

\subsection{Effects of Polysorbate-20 on the Physicochemical Properties of Resveratrol-Loaded Nanoemulsions Stabilized by Bovine and Caprine Caseins}

As noted above, the fluorescence and CD spectroscopy data, especially the CD data concerning complex formation between caprine $\beta$-casein and polysorbate-20, place this protein in a helical conformational niche. The far-UV results, like those from the fluorescence spectra, clearly indicate the compatibility of polysorbate-20's fatty acid chain with the hydrophobicity of caprine casein. The fluorescence data of caprine casein $\alpha_{\mathrm{s} 1}$-II/polysorbate-20 complex presented in Figure 1, therefore, suggest the presence of a significant amount of hydrophobicity in caprine casein $\left(\alpha_{\mathrm{s} 1}\right.$-II). This would argue for a significant amount of $\beta$-casein for the caprine casein $\left(\alpha_{\mathrm{s} 1}\right.$-II) (Table 1$)$. Indeed, the $\beta$-casein content of the caprine caseins used in this study varies from $51.6 \%$ for the caprine casein $\left(\alpha_{\mathrm{s} 1}-\mathrm{I}\right)$ to $60.6 \%$ for the caprine casein $\left(\alpha_{\mathrm{s} 1}-\mathrm{II}\right)$ and, therefore, polysorbate-20 interacts with caprine casein $\left(\alpha_{\mathrm{s} 1}\right.$-II $)$ through hydrophobic interactions.

The hydrophilic and hydrophobic groups in various amino acid sequences and proportions make the bovine casein a candidate with good solubility, which is suitable for food emulsions and as a carrier of bioactive ingredients [38,39]. In bovine milk, casein assembles into micelles consisting of four proteins $\left(\alpha_{\mathrm{s} 1^{-}}, \alpha_{\mathrm{s} 2^{-}}, \beta-\right.$, and $\mathrm{k}$-caseins) via hydrophobic interactions between the four individual caseins and calcium phosphate-mediated salt bridges, and is stabilized by the negative charge and steric repulsion of $\mathrm{k}$-casein [40]. The surface-active and emulsifying properties of bovine casein micelles have been compared to those of sodium caseinate [41]. Interfacial tension results showed 
that caseinate is more surface active than casein micelles at the oil-in-water interface [42]. On the other hand, polysorbate-20 stabilizes emulsions principally through steric repulsion and hence the addition of polysorbate- 20 improves the role of sodium caseinate at the oil-in-water interface in low-pH emulsions [13].

Table 3 shows the mean particle size of the oil droplets in resveratrol-loaded nanoemulsions prepared with bovine and caprine caseins individually and in combination with polysorbate- 20 as emulsifiers (stabilizers) at $0 \mathrm{~h}$. Neither an increase in particle size nor creaming was observed in all of resveratrol-loaded nanoemulsions during 48 -h of storage at $25{ }^{\circ} \mathrm{C}$ (data not shown). It should be noted here that the bovine and caprine caseins of Table 1 were treated with sodium hydroxide before being dried into powders, as described in the Materials and Methods. Therefore, the term casein rather than sodium caseinate is being used in this study. The mean particle range $(205.84 \pm 1.57 \mathrm{~nm}-191.09 \pm$ $2.27 \mathrm{~nm}$ ) of the oil droplets confirmed the suitability of all emulsifying (stabilizing) compounds in the preparation of the resveratrol-loaded emulsions. The interfacial behavior of the emulsifiers may contribute to the differences in droplet sizes [43,44].

Table 3. Particle size and zeta potential of resveratrol-loaded nanoemulsions stabilized with surfactant and protein (emulsifiers).

\begin{tabular}{|c|c|c|}
\hline Emulsifier & ${\text { Particle Size }(\mathrm{nm})^{1}}^{1}$ & Zeta Potential $(\mathrm{mV})^{1}$ \\
\hline Bovine casein & $205.84 \pm 1.57^{\mathrm{a}}$ & $-38.23 \pm 0.29^{c}$ \\
\hline Bovine casein + PS- $20^{2}$ & $202.89 \pm 1.66^{\mathrm{a}}$ & $-37.39 \pm 1.56^{b, c}$ \\
\hline Caprine casein $\left(\alpha_{\mathrm{s} 1}-\mathrm{I}\right)$ & $200.80 \pm 0.45^{\mathrm{a}}$ & $-34.95 \pm 0.18^{a}$ \\
\hline Caprine casein $\left(\alpha_{\mathrm{s} 1}-\mathrm{I}\right)+$ PS-20 & $192.17 \pm 4.61^{\mathrm{b}}$ & $-33.74 \pm 0.95^{\mathrm{a}}$ \\
\hline Caprine casein $\left(\alpha_{\mathrm{s} 1}-\mathrm{II}\right)$ & $200.16 \pm 2.54^{\mathrm{a}}$ & $-35.10 \pm 0.69^{b}$ \\
\hline Caprine casein $\left(\alpha_{\mathrm{s} 1}\right.$-II $)+$ PS-20 & $191.09 \pm 2.27^{b}$ & $-33.89 \pm 1.19^{a}$ \\
\hline
\end{tabular}

${ }^{1}$ Mean value \pm standard error. ${ }^{2}$ PS-20, polysorbate-20. ${ }^{\text {a-c }}$ Means in the same column with different superscripts are significantly different $(p<0.05)$.

Polysorbate-20 is a non-ionic emulsifier with much lower surface tension than water, showing low interfacial tension when mixed with the organic phase, which favors the formation of small droplets $[44,45]$; therefore, the combination of this compound with caprine casein produced emulsions with smaller $(p<0.05)$ particle sizes than using caprine casein individually (Table 3$)$. It can be concluded that, among the emulsifiers (stabilizers), the combination of caprine casein and polysorbate-20 was the best choice in terms of mean particle size of emulsions. The existence of small oil droplets in the resveratrol-loaded nanoemulsions stabilized by the caprine casein/polysorbate- 20 complex suggests that these oil droplets could be effectively taken up by the enterocytes for the improved bioavailability of the bound resveratrol. Leaving phytochemicals in a dispersed state make them more readily absorbed [46]. The delivery system of the present study is MCT oil-based, which diffuses passively from the gastrointestinal tract into the bloodstream, securing a superb bioavailability and a long-lasting effect [46].

All resveratrol-loaded nanoemulsions showed a negative surface charge (zeta potential), and the mixture of either bovine casein or caprine casein with polysorbate-20 produced resveratrol-loaded nanoemulsions with a low net surface charge (Table 3). At the $\mathrm{pH}$ used in this study ( $\mathrm{pH} 7.0)$, the bovine and caprine caseins exhibited a negative charge. The charged groups of interfacial proteins present a barrier to the close approach and coalescence of neighboring droplets [43]. Moreover, the adsorption of $\mathrm{OH}$ groups from resveratrol onto the oil-water interface could also be responsible for the observed negative surface charges. The zeta potentials of the caprine casein-stabilized oil droplets in resveratrol-loaded nanoemulsions were not significantly $(p>0.05)$ affected by the addition of polysorbate-20, and exhibited lower zeta potential values compared with bovine casein in the presence of polysorbate-20 (Table 3). The lower phosphoserine contents of the caprine caseins yield lower zeta potentials [27], but the zeta potentials of the oil droplets were high enough to confer electrostatic repulsive forces. 


\subsection{Stability of Resveratrol}

Emulsions are colloidal systems consisting of three components: the dispersed oil phase, also referred to as oil droplets, the continuous phase, and the oil-water interface stabilized by emulsifiers. The partition of resveratrol and surfactant molecules among the three different components depends on their solubility properties, surface activity, and affinity for the emulsifier at the oil-water interface [42]. The displacement of bovine casein or caprine casein from the oil-water interface did not occur at low polysorbate-20 content $(\leq 1000 \mu \mathrm{M})$. Therefore, all of the polysorbate- 20 interacted with bovine casein or caprine casein without affecting the fraction of milk proteins associated to the oil droplets. Moreover, the resveratrol isomer forms trans-resveratrol and cis-resveratrol were not detected in the continuous phase during processing/storage.

Chemical stability refers to how readily the resveratrol molecule can undergo chemical reactions that modify the hydroxyls and the carbon-carbon double bond [47,48]. The RP-HPLC results indicated that resveratrol degradation occurred in all prepared nanoemulsions due to the high sensitivity of the resveratrol chemical structure to thermal and oxidative stresses during the processing steps and the short-term storage at $25{ }^{\circ} \mathrm{C}$ (Table 4). The degradation of resveratrol in nanoemulsions during processing/storage might be seriously accelerated by the large total surface area of all oil droplets as a result of a size reduction to the nanometer scale [48]. The loss of resveratrol during processing/storage has been attributed to factors such as $\mathrm{pH}$, heat, light, and oxygen [48]. In the present work, the chemical stability of resveratrol was strongly influenced by the emulsifiers used. Thus, caprine casein/polysorbate-20 complex appears to be more effective as an emulsifier than bovine casein/polysorbate-20 complex, and may therefore be the most suitable for stabilizing nanoemulsions that are loaded with resveratrol (Table 4). The role of the emulsifier on resveratrol stabilization appears to be due to the shielding of such hydrophobic phytochemical with a hydrophobic domain provided by a milk protein (e.g., caprine casein) via a surfactant (e.g., polysorbate-20).

Table 4. Persistence of resveratrol in nanoemulsions stabilized with surfactant and protein (emulsifiers) during storage for $48 \mathrm{~h}$ at $25^{\circ} \mathrm{C}$.

\begin{tabular}{cc}
\hline & Persistence of Resveratrol (\%) ${ }^{2}$ \\
\hline Emulsifier $^{1}$ & \\
\hline Bovine casein $^{2}$ & $76.25 \pm 2.67^{\mathrm{c}}$ \\
Bovine casein + PS-20 $^{2}$ & $78.83 \pm 2.61^{\mathrm{c}}$ \\
Caprine casein $\left(\alpha_{\mathrm{s} 1}-\mathrm{I}\right)$ & $83.58 \pm 1.90^{\mathrm{b}}$ \\
Caprine casein $\left(\alpha_{\mathrm{s} 1}-\mathrm{I}\right)+$ PS-20 & $88.33 \pm 1.84^{\mathrm{a}}$ \\
Caprine casein $\left(\alpha_{\mathrm{s} 1}\right.$-II $)$ & $83.50 \pm 1.64^{\mathrm{b}}$ \\
Caprine casein $\left(\alpha_{\mathrm{s} 1}\right.$-II $)+$ PS-20 & $89.08 \pm 2.14^{\mathrm{a}}$ \\
\hline Storage time (hours) & \\
6 & $92.11 \pm 0.99^{\mathrm{a}}$ \\
24 & $86.72 \pm 1.11^{\mathrm{b}}$ \\
48 & $78.06 \pm 1.49^{\mathrm{c}}$ \\
\hline
\end{tabular}

\footnotetext{
${ }^{1}$ Emulsifier data are the mean of samples for each of the time periods studied $(6,12,24$, and $48 \mathrm{~h})$; PS-20 = polysorbate-20. ${ }^{2}$ Mean value \pm standard error. ${ }^{\mathrm{a}-\mathrm{c}}$ Means within each treatment with a different superscript are significantly different $(p<0.05)$.
}

It appears that resveratrol loses persistency in nanoemulsions with time, regardless of the type of emulsifier used (Table 4$)$. However, the mixture of caprine casein $\left(\alpha_{\mathrm{s} 1}-\mathrm{I}\right)$ or caprine casein $\left(\alpha_{\mathrm{s} 1}-\mathrm{II}\right)$ with polysorbate-20 showed the least degradation of resveratrol (Table 4) during processing/storage as quantified by RP-HPLC. The chromatogram obtained at $306 \mathrm{~nm}$ was used for quantitative analysis of trans-resveratrol (Figure 5). Based on the retention time and intensity of the standard, the persistence of resveratrol in nanoemulsions was quantified at $6,12,24$, and $48 \mathrm{~h}$. Significant differences $(p<0.05)$ were observed between the nanoemulsions at $6 \mathrm{~h}$ and the nanoemulsions stored at 12,24 , and $48 \mathrm{~h}\left(\right.$ at $\left.25^{\circ} \mathrm{C}\right)$. 
The mean persistence of resveratrol in nanoemulsions stabilized by caprine casein $\left(\alpha_{\mathrm{s} 1}-\mathrm{I}\right) /$ polysorbate-20 complex was $88.33 \pm 1.84 \%$ during short-term storage at $25^{\circ} \mathrm{C}$ for $48 \mathrm{~h}$. Meanwhile, the mean persistence of resveratrol in caprine casein $\left(\alpha_{\mathrm{s} 1}-\mathrm{II}\right) /$ polysorbate-20 complex was $89.08 \pm 2.14 \%$ during short-term storage at $25{ }^{\circ} \mathrm{C}$ for $48 \mathrm{~h}$. Resveratrol was significantly $(p<0.05)$ less stable in nanoemulsions prepared with caprine casein $\left(\alpha_{\mathrm{s} 1}-\mathrm{I}\right)$ or caprine casein $\left(\alpha_{\mathrm{s} 1}-\mathrm{II}\right)$ in the absence of polysorbate-20 (Table 4$)$. When tested for its ability to minimize the degradation of resveratrol, the bovine casein was found to produce the worst results. The differences in resveratrol degradation among the three caseins appeared to be related to the differences in $\beta$-casein content (Table 1 ).

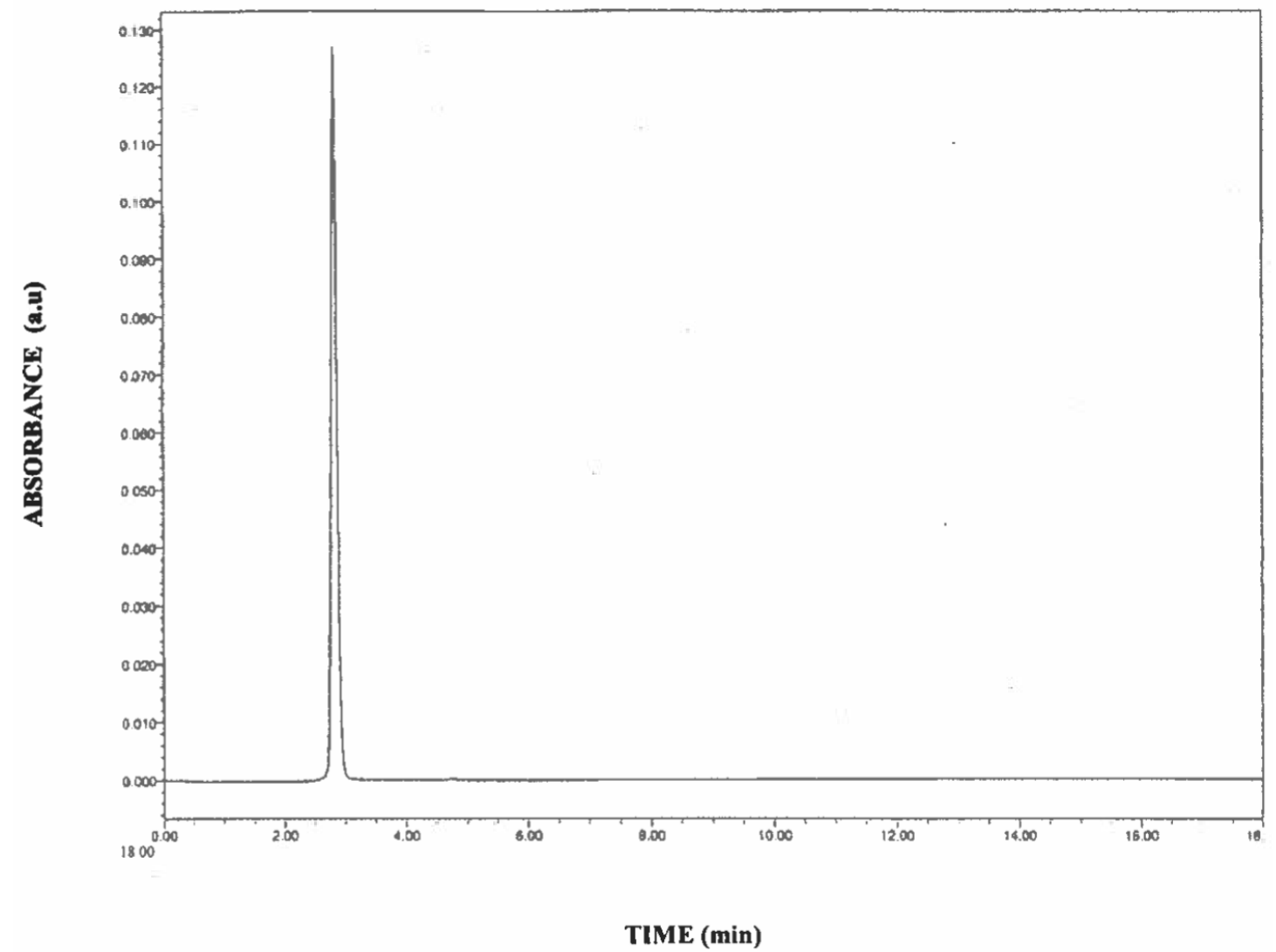

Figure 5. RP-HPLC chromatogram of trans-resveratrol.

Denaturation or unfolding is a general phenomenon specific for globular proteins. Proteins fold in a manner that minimizes the exposure of hydrophobic side chains of the protein to water [49]. The structure that the protein assumes depends on its surrounding environment (buffer solution, storage containers, etc.). In addition, there are intrinsic properties embedded in the primary amino acid sequence that may determine the degree of stability and hence the shelf life of protein products (e.g., protein-stabilized emulsions) [49]. The secondary structure of caprine $\beta$-casein was affected by polysorbate-20, as indicated by the CD spectra (Figure 3). It could be argued the correlation of modified spectra with structural changes is dominated by the interaction upon binding to polysorbate-20, thereby contributing to the pronounced negative ellipticity (Figure 3). The laureate chains of polysorbate-20 associate with disordered regions of casein, promoting the hydrophobic environment [35], which may stabilize the disordered structure and, thereby inducing $\alpha$-helix and sheet conformation (Table 2). The data of Table 2 clearly suggest that polysorbate-20 protects caprine $\beta$-casein from aggregation due to association with disordered regions. Thus, for the better protection of resveratrol in nanoemulsion form, a mixture of caprine casein and polysorbate-20 as stabilizer is a good option.

Moreover, a significant $(p<0.05)$ initial decrease in resveratrol content in the nanoemulsions was observed overtime (Table 4). At 6-h oxidation, the mean persistence of resveratrol was $92.11 \pm$ 
$0.99 \%$ for the bovine and caprine caseins individually and in combination with polysorbate-20. At $48 \mathrm{~h}$ oxidation, the mean persistence of resveratrol was only $76.17 \pm 1.71 \%$ and no differences $(p>0.05)$ were found at 24 and $48 \mathrm{~h}$ in the nanoemulsions during a short-term storage at $25^{\circ} \mathrm{C}$ for $48 \mathrm{~h}$. These results suggest that the loss of resveratrol was fast at the oil-water interface, regardless of the surfactant and protein used. Around $500 \mu \mathrm{g} / \mathrm{mL}$ of the added resveratrol was bound to the bovine and caprine caseins, as described in the Materials and Methods. The binding is mainly governed by hydrophobic interactions close to the tryptophan residues [38]. Caprine caseins, which show higher hydrophobic character due to their high content of $\beta$-casein (Table 1), interact strongly with the resveratrol molecule (Figure 4). Conformational changes in caprine $\beta$-casein caused by the binding of polysorbate-20 can also expose or form hydrophobic environments on the caprine casein $\left(\alpha_{\mathrm{s} 1}-\mathrm{I}\right)$ and caprine casein $\left(\alpha_{\mathrm{s} 1}-\mathrm{II}\right)$. Therefore, the binding of hydrophobic resveratrol to the caprine casein/polysorbate-20 complex is likely to be driven by interaction with caprine $\beta$-casein. A recent study showed that resveratrol was less susceptible to degradation when entrapped in A2 $\beta$-casein from caprine milk and chitosan oligosaccharide [50]. In agreement with these findings, the results of our study implied a possible correlation between caprine $\beta$-casein functionality and the stability of resveratrol.

\section{Conclusions}

A fundamental understanding of the molecular details of the stability of $\beta$-casein will enable us to offer a sound explanation regarding the environmental factors (e.g., $\mathrm{pH}$, heat, light, oxygen) that influence the chemical stability of resveratrol entrapped within a milk protein/surfactant matrix in nanoemulsion delivery systems. The results showed that nanoemulsion delivery systems stabilized by caprine casein and polysorbate- 20 could slow down the degradation of the unstable resveratrol. Further investigations to characterize the chemical degradation of resveratrol in nanoemulsion delivery systems stabilized by emulsifiers (caprine casein, polysorbate-20) and hydrocolloids (polysaccharides) are greatly needed; these can modify the structure and composition of the adsorbed stabilizing layer, with important implications for texture and shelf life.

Author Contributions: Conceptualization: A.M.-G.; methodology: A.M.-G.; formal analysis: A.M.-G., Y.J., S.A.M.; investigation: A.M.-G.; resources: A.M.-G.; data curation: A.M.-G., M.T.N.d.G.; writing-original draft preparation: A.M.-G.; writing-review and editing: A.M.-G., R.A., M.T.N.d.G. All authors have read and agreed to the published version of the manuscript.

Funding: This work was supported by Evans-Allen funding to the Cooperative Agricultural Research Center through the United States Department of Agriculture (USDA) Cooperative State Research Service (CSRS). The last author thanks Kevin Crosby for the scholarship support.

Conflicts of Interest: The authors declare that they have no conflicts of interest.

Ethical Statement: This study does not involve any human or animal testing.

\section{References}

1. Davis, C.; Bryan, J.; Hodgson, J.; Murphy, K. Definition of the Mediterranean diet: A literature review. Nutrients 2015, 7, 9139-9153. [CrossRef] [PubMed]

2. Román, G.C.; Jackson, R.E.; Gadhia, R.; Román, A.N.; Reis, J. Mediterranean diet: The role of long-chain $\omega$-3 fatty acids in fish; polyphenols in fruits, vegetables, cereals, coffee, tea, cacao and wine; probiotics and vitamins in prevention of stroke, age-related cognitive decline, and Alzheimer disease. Rev. Neurol. 2019, 175, 724-741. [CrossRef] [PubMed]

3. Galiniak, S.; Aebisher, D.; Bartusik-Aebisher, D. Health benefits of resveratrol administration. Acta Biochim. Pol. 2019, 66, 13-21. [CrossRef] [PubMed]

4. Thaung Zaw, J.J.; Howe, P.R.C.; Wong, R.H.X. Sustained cerebrovascular and cognitive benefits of resveratrol in postmenopausal women. Nutrients 2020, 12, 828. [CrossRef]

5. Amri, A.; Chaumeil, J.C.; Sfar, S.; Charrueau, C. Administration of resveratrol: What formulation solutions to bioavailability limitations? J. Control. Release 2012, 158, 182-193. [CrossRef] 
6. Francioso, A.; Mastromarino, P.; Masci, A.; d'Erme, M.; Mosca, L. Chemistry, stability and bioavailability of resveratrol. Med. Chem. 2014, 10, 237-245. [CrossRef]

7. Summerlin, N.; Soo, E.; Thakur, S.; Qu, Z.; Jambhrunkar, S.; Popat, A. Resveratrol nanoformulations: Challenges and opportunities. Int. J. Pharm. 2015, 479, 282-290. [CrossRef]

8. McClements, D.J. Enhanced delivery of lipophilic bioactives using emulsions: A review of major factors affecting vitamin, nutraceutical, and lipid bioaccessibility. Food Funct. 2018, 9, 22-41. [CrossRef]

9. Liu, Q.; Huang, H.; Chen, H.; Lin, J.; Wang, Q. Food-grade nanoemulsions: Preparation, stability and application in encapsulation of bioactive compounds. Molecules 2019, 24, 4242. [CrossRef]

10. Leaver, J.; Horne, D.S.; Law, A.J.R. Interactions of proteins and surfactants at oil-water interfaces: Influence of a variety of physical parameters on the behavior of milk proteins. Int. Dairy J. 1999, 9, 319-322. [CrossRef]

11. Fuller, G.T.; Considine, T.; MacGibbon, A.; Golding, M.; Matia-Merino, L. Effect of Tween emulsifiers on the shear stability of partially crystalline oil-in-water emulsions stabilized by sodium caseinate. Food Biophys. 2018, 13, 80-90. [CrossRef]

12. Cheong, J.N.; Mirhosseini, H.; Tan, C.P. Effect of polyoxyethylene sorbitan esters and sodium caseinate on physicochemical properties of palm-based functional lipid nanodispersions. Int. J. Food Sci. Nutr. 2010, 61, 417-424. [CrossRef] [PubMed]

13. Perugini, L.; Cinelli, G.; Cofelice, M.; Ceglie, A.; Lopez, F.; Cuomo, F. Effect of the coexistence of sodium caseinate and Tween 20 as stabilizers of food emulsions at acidic pH. Colloid Surf. B. 2018, 168, 163-168. [CrossRef] [PubMed]

14. Tual, A.; Bourles, E.; Barey, P.; Houdoux, A.; Desprairies, M.; Courthaudon, J.L. Effect of surfactant sucrose ester on physical properties of dairy whipped emulsions in relation to those of $\mathrm{o} / \mathrm{w}$ interfacial layers. $J$. Colloid Interface Sci. 2006, 295, 495-503. [CrossRef]

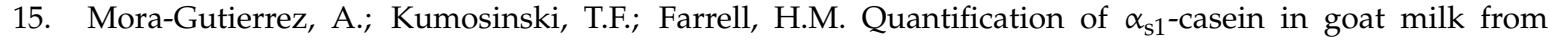
French-Alpine and Anglo-Nubian breeds using reversed-phase high performance liquid chromatography. J. Dairy Sci. 1991, 74, 3303-3307. [CrossRef]

16. Basch, J.J.; Farrell, H.M.; Walsh, R.A.; Konstance, R.P.; Kumosinski, T.F. Development of a quantitative model for enzyme-catalyzed, time-dependent changes in protein composition of cheddar cheese during storage. J. Dairy Sci. 1989, 72, 591-603. [CrossRef]

17. Mercier, J.C.; Maubois, J.L.; Poznańzky, S.; Ribadeau-Dumas, B. Preparative fractionation of cows' and ewes' milk caseins by chromatography on DEAE-cellulose in a medium containing urea and 2-mercaptoethanol. Bull. Soc. Chim. Biol. 1968, 50, 521-530.

18. Moatsou, G.; Mollé, D.; Moschopoulou, E.; Valérie, G. Study of caprine $\beta$-casein using reversed-phase high-performance liquid chromatography and mass spectroscopy: Identification of a new genetic variant. Protein J. 2007, 26, 562-568. [CrossRef]

19. Acharya, D.P.; Sanguansri, L.; Augustin, M.A. Binding of resveratrol with sodium caseinate in aqueous solutions. Food Chem. 2013, 141, 1050-1054. [CrossRef]

20. Wiedemann, C.; Bellstedt, P.; Görlach, M. CAPITO-a web server-based analysis and plotting tool for circular dichroism data. Bioinformatics 2013, 29, 1750-1757. [CrossRef]

21. Steiner, B.M.; Shukla, V.; McClements, D.J.; Li, Y.O.; Sancho-Madriz, M.; Davidov-Pardo, G. Encapsulation of lutein in nanoemulsions stabilized by resveratrol and Maillard conjugates. J. Food Sci. 2019, 84, 2421-2431. [CrossRef] [PubMed]

22. Markwell, M.A.; Haas, S.M.; Bieber, L.L.; Tolbert, N.E. A Modification of the Lowry procedure to simplify protein determination in membrane and lipoprotein samples. Anal. Biochem. 1978, 87, 206-210. [CrossRef]

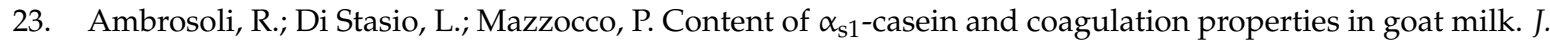
Dairy Sci. 1988, 71, 24-28. [CrossRef]

24. Grosclaude, F.; Mahé, M.F.; Brignon, G.; Di Stasio, L.; Jeunet, R. A Mendelian polymorphism underlying quantitative variations of goat $\alpha_{\mathrm{s} 1}$-casein. Genet. Sel. Evol. 1987, 19, 399-412. [CrossRef] [PubMed]

25. Jaubert, A.; Martin, P. Reverse-phase HPLC analysis of goat caseins. Identification of $\alpha_{\mathrm{s} 1}$ and $\alpha_{\mathrm{S} 2}$ genetic variants. Lait 1992, 72, 235-247. [CrossRef]

26. Kumosinski, T.F.; Brown, E.M.; Farrell, H.M. Three-dimensional molecular modeling of bovine caseins: An energy-minimized $\beta$-casein structure. J. Dairy Sci. 1993, 76, 931-945. [CrossRef] 
27. Mora-Gutierrez, A.; Attaie, R.; Farrell, H.M. Lipid oxidation in algae oil-in-water emulsions stabilized by bovine and caprine caseins. J. Agric. Food Chem. 2010, 58, 5131-5139. [CrossRef]

28. Mora-Gutierrez, A.; Attaie, R.; Núñez de González, M.T.; Jung, Y.; Woldesenbet, S.; Marquez, S.A. Complexes of lutein with bovine and caprine caseins and their impact on lutein chemical stability in emulsion systems: Effect of arabinogalactan. J. Dairy Sci. 2018, 101, 18-27. [CrossRef]

29. Lakowicz, J.R. On spectral relaxation in proteins. Photochem. Photobiol. 2000, 72, 421-437. [CrossRef]

30. Kelkar, D.; Chanudhuri, A.; Haldar, S.; Chattopadhyay, A. Exploring tryptophan dynamics in acid-induced molten globule state of bovine $\alpha$-lactalbumin: A wavelength-selective fluorescence approach. Eur. Biophys. J. 2010, 39, 1453-1463. [CrossRef]

31. Kratz, F.; Elsadek, B. Clinical impact of serum proteins on drug delivery. J. Control. Release 2012, 161, 429-445. [CrossRef] [PubMed]

32. Lucey, J.A.; Otter, D.; Horne, D.S. A 100-Year Review: Progress on the chemistry of milk and its components. J. Dairy Sci. 2017, 100, 9916-9932. [CrossRef] [PubMed]

33. Sun, Y.; Oseliero Filho, P.L.; Oliveira, C.L.P. $\alpha$-Lactalbumin and sodium dodecyl sulfate aggregates: Denaturation, complex formation and time stability. Food Hydrocoll. 2017, 62, 10-20. [CrossRef]

34. Perticaroli, S.; Nickels, J.D.; Ehlers, G.; Mamontov, E.; Sokolov, A.P. Dynamics and rigidity in an intrinsically disordered protein, $\beta$-casein. J. Phys. Chem. B 2014, 118, 7317-7326. [CrossRef] [PubMed]

35. Hu, X.Y.; Zhang, X.; Chen, D.; Li, N.; Hemar, Y.; Yu, B.; Tang, S.; Sun, Y. How much can we trust polysorbates as food protein stabilizers-The case of bovine casein. Food Hydrocoll. 2019, 96, 81-92. [CrossRef]

36. Sun, Y.; Filho, P.L.O.; Bozelli, J.C.; Carvalho, J.; Schreier, S.; Oliveira, C.L.P. Unfolding and folding pathway of lysozyme induced by sodium dodecyl sulfate. Soft Matter 2015, 11, 7769-7777. [CrossRef]

37. Gorji, E.G.; Rocchi, E.; Schleining, G.; Bender-Bojalil, D.; Furtmüller, P.G.; Piazza, L.; Iturri, J.J.; Toca-Herrera, J.L. Characterization of resveratrol-milk protein interaction. J. Food Eng. 2015, 167, $217-225$. [CrossRef]

38. Cheema, M.; Hristov, A.N.; Harte, F.M. The binding of orally dosed hydrophobic active pharmaceutical ingredients to casein micelles in milk. J. Dairy Sci. 2017, 100, 8670-8679. [CrossRef]

39. Głąb, T.K.; Boratyński, J. Potential of casein as a carrier for biologically active agents. Top. Curr. Chem. 2017, 375, 71. [CrossRef]

40. Kamigaki, T.; Ito, Y.; Nishino, Y.; Miyazawa, A. Microstructural observation of casein micelles in milk by cryo-electron microscopy of vitreous sections (CEMOVIS). Microscopy 2018, 67, 164-170. [CrossRef]

41. Courthaudon, J.L.; Girardet, J.M.; Campagne, S.; Rouhier, L.M.; Campagna, S.; Linden, G.; Lorient, D. Surface active and emulsifying properties of casein micelles compared to those of sodium caseinate. Int. Dairy J. 1999, 9, 411-412. [CrossRef]

42. Tcholakova, S.; Denkov, N.D.; Ivanov, I.B.; Campbell, B. Coalescence stability of emulsions containing globular milk proteins. Adv. Colloid Interface Sci. 2006, 123-126, 259-293. [CrossRef] [PubMed]

43. McClements, D.J.; Bai, L.; Chung, C. Recent advances in the utilization of natural emulsifiers to form and stabilize emulsions. Annu. Rev. Food Sci. Technol. 2017, 8, 205-236. [CrossRef] [PubMed]

44. Dickinson, E.; Ritzoulis, C.; Povey, M.J. Stability of emulsions containing both sodium caseinate and Tween 20. J. Colloid Interface Sci. 1999, 212, 466-473. [CrossRef]

45. Singh, Y.; Meher, J.G.; Raval, K.; Khan, F.A.; Chaurasia, M.; Jain, N.K.; Chourasia, M.K. Nanoemulsion: Concepts, development and applications in drug delivery. J. Control. Release 2017, 252, 28-49. [CrossRef]

46. Kennedy, D.; Wightman, E.; Khan, J.; Grothe, T.; Jackson, P. The acute and chronic cognitive and cerebral blood-flow effects of Nepalese pepper (Zanthoxylum Armatum DC.) extract-A randomized, double-blind, placebo-controlled study in healthy humans. Nutrients 2019, 11, 3022. [CrossRef]

47. Tian, B.; Liu, J. Resveratrol: A review of plant sources, synthesis, stability, modification and food application. J. Sci. Food Agric. 2020, 100, 1392-1404. [CrossRef]

48. Leyva-Porras, C.; Saavedra-Leos, M.Z.; Cervantes-González, E.; Aguirre-Bañuelos, P.; Silva-Cázarez, M.B.; Álvarez-Salas, C. Spray drying of blueberry juice-maltodextrin mixtures: Evaluation of processing conditions on content of resveratrol. Antioxidants 2019, 8, 437. [CrossRef] 
49. Ho, R.J.Y.; Gibaldi, M. Clinical pharmacology, toxicology, and their therapeutics. In Biotechnology and Biopharmaceutical. Transforming Proteins and Genes into Drugs; Wiley: Hoboken, NJ, USA, 2003.

50. Kim, M.Y.; Ha, H.K.; Ayu, I.L.; Han, K.-S.; Lee, W.-J.; Lee, M.-R. Manufacture and physicochemical properties of chitosan oligosaccharide/A2 $\beta$-casein nano-delivery system entrapped with resveratrol. Food Sci. Anim. Resour. 2019, 39, 831-843. [CrossRef] 